\title{
IN SEARCH OF POLYNESIAN ORIGINS: WITH SPECIAL REFERENCE TO LAPITA CULTURE
}

\author{
Timbul Haryono
}

"The problem of Polynesian origins and cultural diffusion is far too complex to be solved... The variety of possible sources and of possible routes is infinite".

(Ferdon, 1963).

\section{Introduction}

The islands of Polynesia make up the largest group among the islands in the Pacific ocean. This group, in fact, consist of many islands forming a triangle. The main groups in the west are the Tongan, and Samoan and Ellice groups. The Cook, Society and Tuamotus lie in the east, with Easter Island as a far-off isolate, while the Hawaiian Islands and New Zealand are separated to the north and south respectively of the main west-east belt.

The location of these islands between Asia in the west. Australia in the south and South America continent in the east is of considerable significance to the peopling and cultural development of the region. Many scholars have therefore been led to postulate the route of human movement into these scattered islands. Archaeological and anthropological researches have been carried out within the area to determine where the Polynesians originally come from. Various hypotheses have been proposed thereafter.

Basically, there are two hypotheses which deal with the origins of the Polynesians: South American-Indian on one hand, and Southeast Asian on the other. The controversy that ensued over East versus West as the source of the people and 'culture of Polynesia' has tended not only to obscure the complexity of the problem but also to conceal the numerous other possibilities since the days 
of Captain Cook (Ferdon, 1963:499). Such passages as that quoted in the beginning of this chapter represent how complex the problem remains.

The purpose of this paper is to summarize the ideas which have been proposed. On the basis of current discoveries, special attention is focused on the Lapita culture. The external relationships of this distinctive culture are also taken into account to highlight the problems which remain to be solved.

\section{South-American Indian hypothesis}

The hypothesis that the Polynesians were originally come from South America was put forward by Thor Heyerdahl in 1941. He believed that Polynesia was first settled by Caucasoids from the area of Tiahuanaco in Bolivia. These people moved into the Pacific arround 800 A.D. and then the true Polynesians moved down from British Columbia between 1100 and 1300 A.D. settling among the earlier Caucasoids and gradually replacing them.

Heyerdahl was unable to accept the theory that the Polynesians had migrated through Melanesia because of racial differences: and he believed that the Polynesian languages were unrelated to Malay for Sanskrit words, present in Indonesian languages since before A.D. 500, were absent in Polynesia.

To test his hypothesis, he carried out the 'Kon-Tiki Expedition In 1947 a balsa raft was constructed called the Kon-Tiki. Heyerdahl and his colleagues set out from Callao to show that South American Indians could have settled Polynesia by following the prevailing winds and currents. After sailing with winds and currents for 101 days they were washed ashore on the atoll of Raroia in Tuamotus. and thus showed that South American Indians could indeed have reached Polynesia (Heyerdahl, 1950a, 1950b, 1952).

He pointed out (Heyerdahl, 1961), on the basis of material culture, that no characteristic Polynesian artifacts appear in Indonesia or on 
the Micronesian-Melanesian islands separating the two areas. The basic tool, as in all Polynesia was an adze rather than an axe. One of the most specialized adze blades in Polynesia reappears archaeologically on the Northwest American coast. The other specialized artifacts such as bell-shaped, D-shaped, and T-shaped stone pounders were entirely missing in Southeast Asia (Heyerdahl, 1961:26). Other practices unknown in Indonesia but found in Polynesia include mummification, utilizing a method corresponding to that used in Peru, and also the special single and composite fishhooks of Polynesia, none of which are known in Indonesia, but which appear sporadically in archaeological middens from Equador down to northern Chili.

It is apparent that Heyerdahl's theory was based upon the similarity of individual cultural elements. The validity of this is very dubious since a cultural parallel might be another explanation of such similarity. A cultural parallel, according to the definition of Roland B. Dixon (1928:182) means the phenomenon of the existence of cultural traits or trait-complexes which seem to be similar or even identical, in two more or less widely-separated areas, between which there has been no known contact. The similarity is due to chance and the basic unity of the human mind, which, confronted with similar conditions, has reacted to them in a similar way.

Botanical evidence has been of great significance to support the American-Indian origin of the Polynesians. E.D. Merrill (cited by Heyerdahl, 1964) who studied the geographic distribution of the Gossypium genus (cotton) assumed that direct American-Polynesian contacts in pre Columbian times did occur and he suggested that the natives of South American reached some of the Pacific islands on. balsa rafts. Similarly, Heyerdahl takes the kumara (sweet-potato) as an evidence that togther with several other useful plants in the New World it was carried by pre-European voyagers from South America to Polynesia. Noteworthy is the fact that the name kumara for sweet-potato has wide geographical distribution in southern Panama, Columbia, Equador, Peru, Polynesia and Melanesia. 
Other scientists have focused on a blood group genetical survey (Graydon, 1952; Simmons, Graydon, Sample, and Fry, 1955; Simmons and Graydon, 1957). J.J. Graydon, scientist from Commonwealth Serum laboratories, Melbourne, has plotted the A-B-O data among the Polynesians and compared it to that of the American Indian. He reached the conclusion that the blood patterns of these two adjacent people were "strikingly similar", and that "both are remarkably unlike the blood pattern of Melanesia and Mieronesia". In respect of $\mathrm{A}, \mathrm{B}, \mathrm{O}$ groups, the Polynesian is closer to the American Indian than to either the Melanesian or Micronesian. He stated: "... that the serological evidence... supports a PolynesianAmerindian relationship, making it probable that the islands of Polynesia have been settled largely by migrations from Continental America" (Graydon, 1952:338).

Working with blood samples from eastern Polynesia collected by the Norwegian Archaeological Expedition to Easter Island and the East Pacific, the results obtained are comparable with those previously reported for Maories of New Zealand and Cook Islanders, and in a number of characters are comparable with some South American Indian tribes (Simmons and Graydon, 1957:365). No such similarity is evident when comparisons are made with Melanesians, Micronesians, and Indonesians. As was the case with Easter Islanders, there is also a close blood genetic relationship between American Indians and the Cook Islanders (Simmons, 1961; Simmons, Graydon, Sample, and Fry, 1955).

So far, the serological evidence and the botanical evidence seem to support Heyerdahl's hypothesis. But as far as the hypothesis is concerned, the Kon-Tiki expedition and serological survey are subject to criticism. Robert C. Suggs (1970) criticised the Kon-Tiki voyage as not a fair test of the sailing ability of the ancient Peruvians by any means. Its basis is mainly the success of a modern raft voyage that could not hope to prove anything concerning ancient Peruvian navigation. The Kon-Tiki voyage, as Suggs (1970:34) stated, 
" proved only this: that by using a modern, Post-European-contact type of sailcraft with navigation aids and modern survival equipment, man can survive a 101-day voyage between Peru and Polynesia". Regarding the blood grouping, the very disparate races may have similar blood-type frequencies and that blood typing alone is meaningless for a comparison of two groups of people, if their morphological characteristics are dissimilar.

E.N. Ferdon (1963) stated that for serological evidence it is insufficient to determine the present blood groups and gene frequencies for Polynesians and for other, surrounding racial groups and from these comparative data draw a conclusion about racial relationships. For Ferdon, processes of microevolution and selection especially those selective factors that have operated in historic times through the decimation of native populations by European diseases must be determined and taken into account. In fact, the Polynesian is too complex to be derived. The complexity of the Polynesian population has been studied by R.B. Dixon in the 1920's by making a correlation for the cephalic, length-height and nasal indices.

R.B. Dixon (1920) found three fundamental types: (1) The underiying and probably historically the oldest of the fundamental types in Polynesia is one which is practically identical with that of the Negrito. This type was the Brachycephalic, Hypsicephalic, Platyrrhine group. This type is distributed in the Hawaiian Islands. (2) The second in historical sequence is the Dolichocephalic, Hypsicephalic, Platyrrhine type, whose proximate affiliations lie with the negroid population of Melanesia and Australia. The geographical distribution of this type is marginal: Easter Island on the eastern fringe of the area. (3) The third and clearly the latest type which has contributed to the making of the Polynesian people, and the one whose influence has long been preponderant over a large part of the area, is one which is Brachycephalic, Hypsicephalic and Leptorrhine. This type forms a very important factor in the rather complex Malayan and 
Eastern Asiatic population. This type seems strongest in Samoa and Tonga in the West, and in the southern islands of the Hawaiian group.

Others like D: Oliver (1961) summarized the occupation of Oceania as follows:

- Negritos, who are short-statured, dark-skinned, probably pushed out of southern Asia during the last glacial period.

- the Negrito migration to Oceania must have required many thousand years.

- during the fourth glacial epoch. possibly prior to the migration of the Negrito, bands of different kind of human hunters and food gatherers moved from Malaysia out into New Guinea and Australia.

- Millennia before the Christian era, the so-called 'Indonesian' racial type (not to be confused with-the term now being applied in a political sense to citizens of the Republic of Indonesia) began moving down into Malaysia.

- At an early period (c. 4000 B.P.) hybridized Indonesians began settling along the coasts of New Guinea and the other islands of Melanesia.

- Some went to populate eastern Micronesia, Palau, Yap and the Marianas, others went to Fiji, and then on to Tonga and Samoa, and developed the somewhat distinctive way of life now known as Polynesian.

It seems that the racial elements are ever blending and shifting as a result of which it seems impossible to sort them out and fit them into a patterned schema. As Swindler (1968:41) observed, populations as seen today are the products of mutation, migration, natural selection, genetic drift, and selective mating, all of which have effectively contributed to the racial diversity so demonstrable there today. 
While blood group serology does not prove to us who they were or from whence they came, some therefore assumed that the Polynesian people spread mainly by accidental voyages to all the distant Polynesian islands over a long period of time rather than by deliberate planned migrations (Simmons 1961:209; Swindler, 1968: 43), a theory which has been proposed by Andrew Sharp (1956) before. Sharp's (1963) hypothesis of 'one-way voyaging', that Polynesians might be able to reach distant islands, but would never find their way back home again, was said to be somewhat in doubt.

The two types of voyagers - those who migrated intentionally and those who migrated unintentionally - could be distinguished in that the former carried with them as much of their human and cultural heritage as they could, whereas the later brought to an island refuge only their personal knowledge and concepts of their original cultural worlds and any objects which happened to be aboard. The latter seems hardly probable if one accepts that the direction of movement is from west to east, thus in the face of prevailing winds (Clark, 1977:491). As we know that the islands are scattered widely over great ocean spaces, and viable populations of humans, plants and animals got through as well, we may conclude that it is unlikely that these would be carried on some mere drifting canoe. At least one population group which entered Polynesia developed or maintained a cultural tradition of intentional migratory voyaging (Ferdon. 1963:501).

\section{Southeast Asian hypothesis}

In the earlier discussion it has been pointed out that to search for the origins of Polynesian in South America is unlikely. The blood group does not provide firm evidence since most of the analyses have been based on living populations whose blood groups may have changed over time. If the Polynesians do resemble in appearance to the South American Indians this does not necessarily mean that the Polynesians must be derived from South American Indians. Rather 
the latter are also Mongoloids of ultimate East Asian derivation, as are the Polynesians.

The most favorable hypothesis regarding the origins of the Polynesians is that they are derived from the west. There are many reasons for thinking that the Polynesian islands were peopled from the west. Linguistic as well as archaeological evidence strongly support this idea.

\section{Linguistic data}

Polynesian languages form one branch of a very wide-spread language family known as Austronesian or Malayo Polynesian. The Austronesian languages as a whole are spoken through out Indonesia, the Phillipines, Micronesia, Polynesia, Madagascar, parts of South Vietnam and Malaya, and Melanesia. The languages of Polynesia form a minor branch of the whole Austronesian family.

Linguists have assumed that the first settlement in the Polynesian triangle probably took place in the Tongan Islands. Then these earliest Polynesians spread through the northern islands of the Tongan group to Samoa, and the ancestral Polynesian languages gradually underwent a major separation into the Tongic and Nuclear Polynesian subgroups. Wurm (1967) outlined the picture of the sequence of intra-Polynesian differentiations as follows:

(1) The first split seperates Tongic (Tongan, Niue, and possibly Uvean) from Nuclear Polynesian.

(2) Nuclear Polynesian subsequently differentiated into a Samoic subgroup (Samoan, Futunan, Ellice, Tokelauan, Tikopian, and possibly Uvean) and Eastern Polynesian. Most, probably all, of the Polynesian outlier languages in Melanesia and Micronesia belong to the Nuclear Polynesian subgroup and possibly to Samoic.

(3) Eastern Polynesian subsequently split into Eastern Island and Central Polynesian.

(4) Thereafter, Central Polynesian split into Tahitic (Tahitian, Rarotongan, Maori, Tuamotuan) and Marquesic. 
(5) Marquesic differentiated into Mangarevan and Marquesan.

(6) Marquesan split into Northwest Marquesan and Southeast Marquesan.

Green (1966) suggests some dates for the various separations listed above:

(1) The split of Tongic from Nuclear Polynesian is assumed to have taken place around 500 B.C.

(2) The differentiation of Eastern Polynesian from Nuclear Polynesian is believed to have taken place around 100 A.D. or earlier.

(3) The split of Eastern Polynesian into the language Easter Island and Central Polynesian is dated between 300 and 400 A.D., that of Central Polynesian into Tahitic and Marquesic after 530 A.D. and before 650 A.D. and that of Marquesic into Mangarevan and Marquesan between 800 and 850 A.D.

(4) The differentiation of Hawaiian probably took place not long after the split of Marquesan into North-west Marquesan and Southeast Marquesàn.

It is worth pointing out that Polynesian languages show no convincing evidence of substrata from South America. The hypothesis that the original homeland of Austronesian is in the west rather than in the east is also supported by the evidence indicating that Austronesian as a whole is related to a group of languages (ThaiKadai) in Southeast Asia (Benedict, 1942). Clark (1977:488) noted that the relationships of the Polynesian languages, like those of Melanesia and Indonesia, rest with Thai, Kadai and Li (Formosan). With regard to the relationship between Polynesian and Melanesian language, it was thought that Polynesian languages are simply continuations of a single earlier. Melanesian language (Grace, 1970); as Grace (197.0:25) has observed, as far as linguistic data are concerned, either the Polynesians came from Melanesia or they came from somewhere else and acquired a Melanesian language. 
Grace (1964) is studying the chronological movement of the Malayo-Polynesian languages suggested that Malayo-Polynesian languages were already widely distributed in Taiwan. Indonesia, Melanesia and probably the Phillipines by 1500 B.C. or shortly thereafter. Subsequent movements after approximately 1500 B.C. probably led to the establishment of Malayo-Polynesian languages in Fiji, Polynesia, (most if not all of) Micronesia, and Madagascar. According to Grace, the movement to Fiji, to Polynesia, and to most of Micronesia might have been originated in the New Hebrides.

\section{Botanical and faunal data}

The major cultivated plant foods include taro, yam, sweet potato. coconut, breadfruit and banana. With the exception of sweet potato all of these cultivated plants are of Southeast Asian origin. The sweet potato (Ipomoea batatas) is of Andean origin.

Hui-Lin Li (1970) in his study on the origin of cultivated plants in Southeast Asia divided the region from northern China south wards to the Indonesian island into four main latitudinal zones: (1) the Northern China Belt, (2) the Southern China Belt, (3) the Southern Asia Belt, and (4) the Southern Islands Belt. To note oniy the last two belts we have the following plant inventories. The main staple crop that originated here is rice (Oryza sativa). Others which are of great importance and form a distinctive feature of the Pacific region are tuber crops. Among those that originated here are taro (Colocasia antiquorum), ape (Alocasia macrorrhiza), yam (Dioscorea esculenta), and the greater yam (Dioscorea alata). The banana (Musa x paradisiaca), the sugarcane (Saccharum officinarum), breadfruit (Artocarpus altilis), jackfruit (Artocarpus integra), and coconut (Cocos nucifera) are widely cultivated flora of the Southern Island Beit since very ancient times ( $\mathrm{Li}, 1970: 12-14)$. The most distinctive features of the cultivated plants that originated in the Southern Island Belt are the presence of tuber plants and the absence of cereals and legumes among the staple crops. 
A number of other plants of Southeast Asian origin cultivated by the Polynesian included the paper mulberry tree (Broussonetia papyrifera), which provided an inner bark used for making felted cloth (tapa) and the small shrub Piper methysticum, a root of which was chewed and mixed with water to provide a stupefying drink known as kava. The drinking of kava was an important aspect of many ceremonies in western Polynesia and Fiji (Béllwood, 1978: 36).

All the plants of Asian origin cultivated by the Polynesians could only have been brought there by man. Shutler and Marck (1975) have already considered the problem of the origins and dispersal of Austronesian speaking horticulturalists into Insular Southeast Asia and the Pacific by combining linguistic and archaeological evidence. They reasonably suggest a movement into the Pacific at an approximate date of 4000 B.C. (Shutler and Marck, 1975: 103 - 107). Likewise the only domesticated animals, pigs, dog and jungle cock all came from Southeast Asia (Sauer, 1952). They must have been carried thence over great tracts of the Pacific Ocean together with the domesticated plants on which men and their pigs mainly fed. It was reported that the chicken was the only domestic animal to reach Easter island and only the dog came to New Zealand during the pre-colonial period. Chicken as well as pig were brought to the Marquesas and dog as well to Hawaii (Clark, 1977:492). Archaeologically, pig bones dating from about 3000 B.C. were reported from Kiowa and Kafiavana, New Guinea. If we accept the idea that the colonization of the Polynesia began from the western margin of the Pacific (Oliver, 1961; Suggs, 1960) we would expect to uncover such animal bones from archaeological deposit in Polynesia after the third millennium B.C.

\section{Lapita Culture}

The immediate origins of the Polynesian culture have in recent years become identified with certain early sites, from New Britain to Tonga, containing a type of pottery known as Lapita after an 
important site in New Caledonia (site 13) where it was found (Gifford and Shutler. 1956:7). The discovery of Lapita pottery was initially made in $1908-1909$ by Otto Meyer, on the island of Watom. in central Melanesia; but it was not until the archaeological recovery of similar pottery from sites in New Caledonia, Fiji, and Tonga between 1947 and 1957 that a foundation was laid for understanding the important position of Lapita in the prehistory of the Pacific.

Lapita style decorated pottery has a very special place in the Pacific prehistory, on account of: (1) its widespread distribution, from New Guinea to Tonga; (2) its possible relationships to pottery from the Philippines, Southeast Asia, and South China; and (3) the pos sibility that it represents one of the earliest. if not the earliest intrusions by man into the islands of the Southwest Pacific.

The pottery of the Lapita culture has distinctive geometric designs using both dentate stamping and incising as major decorative techniques. They are well-made paddle and anvil ware which also possessed zoomorphic elements models of people and birds. drawings of human face masks. The method of decoration and the motifs employed were widely spread over Fiji, Tonga, and Watom Island.

In Tonga. archaeological fieldwork was carried out in $1963-$ 1964 (Poulsen 1964) after the first finds of prehistoric pottery were made by W.C. mcKern in $1920-1921$. The pottery ornamentation found in the sites is generally geometric. The most common techniques are 'incising' and 'rouletting', the former made by pressing a pointed tool into the clay and drawing it along the surface, the latter by rolling a wheel with a toothed edge along the surface (Poulsen, 1964:185). Many of the motifs have paraliels among the sherds from Site 13 Lapita and at St. Maurice in New Caledonia (Golson, 1961:174).

L.M. Groube (1971) studied the Lapita ware from Tonga as a means of interpreting Polynesian origins and concluded that the 
Polynesians became Polynesian sometime near the middle of the first millennium B.C. after over 600 years of isolation in the remote archipelago of Tonga. "The Polynesians, therefore, did not strictly come from anywhere: they became Polynesians and the location of their becoming was Tonga" (Groube, 1971:313). He characterized the Lapita people as "Oceanic strandloopers".

In the Main Reef Group on the nearby high island of Santa Cruz, Green (1973) also found sites with Lapita ware. The sites reported have provided various shapes of pottery vessels, ovens, pits, stone adzes, and flake tools. The settlements with Lapita pottery in these areas date from a time between 1000 and 500 B.C., an age range entirely compatible with that of Lapita sites in Eastern Melanesia and Polynesia. Green (1973:337) hypothesized that the cultural complex associated with Lapita pottery in Melanesia is an ancestral base from which the earliest culture of Polynesia must be derived.

John D. Hedrick, of the University of Pennsylvania, in 1968 located three Lapita style pottery sites on Malo Island: the Aunitare, the Aunambulu, and the Alawara site. Malo, formerly known as St. Batholoneew Island, is situated between Espiritu Santo and Malekula in the northern district of the New Hebrides Islands. A total of 683 potsherds was recovered from the site of Aunitare. Of these, 681 were identified and assigned to the Lapita tradition (Hedrick, 1971). As was the case in the Lapita tradition, the pottery was constructed by the slab method and finished with paddle and anvil. The design motifs are varied with exclusive use of geometric motifs in the form of circles, semi-circles, squares, crescents, diamonds, and many others. Many of the geometric motifs are comparable to those of sherds from Fiji (Palmer, 1966:fig.1;5), New Caledonia (Gifford and Shutler, 1956: pl. 16; 17;22; 23), and Tonga (Poulsen, 1964:fig. 4; 6;11;14;16;21). The plastic techniques used in the decoration of the pottery are incising, dentate stamping 
(including circle stamping), and cord marking. The dating of the initial settlement horizon is c. 70 B.C. (UCLA-1412). This is very late compared with the much earlier dates of c. 1000 B.C. reported from Fiji and New Caledonia, and c. 500 B.C. reported by Specht (1968:124) from Watom Island and by Poulsen from Tonga.

On Watom Island, prehistoric pottery with and unusual and distinctive decoration, or 'Lapita Style', was reported by Otto Meyer in 1909. One was found at Rakival village, and another in Vunakabai village. In 1966, J. Specht excavated some sites at Rakival which yielded a total of 4028 sherds, as well as bone, shell, and stone artifacts. Fron these sherds, Specht (1968:128 - 130) identified four decorative techniques: applied relief, linear incision, nail impressions, and dentate stamping. The most striking feature of all the decorated sherds is the exclusive use of geometric motifs; other distinctive features are closeness of spacing, symmetry of spacing, and also the strict zonation of the motifs in that each motif band is clearly separated from the next. The motifs and techniques employed are comparable with those of New Hebrides, New Caledonia site 13, and St. Maurice site.

Radiocarbon dates from the sites have been reported by H.A. Polach, of Radiocarbon Dating Laboratory, ANU as the following:

ANU-37b: $2420 \pm 110(470 \mathrm{BC})$ from site 8 , trench I. This is the earliest of the Watom Island series, though not necessarily dating the earliest occupation of the Rakival site complex.

ANU--72 : $720 \pm 57$ (AD 1230) from site 6, tr. VII, zone $2 \mathrm{~b}$.

ANU-74 : $780 \pm 100$ (AD 1170) from site $6 \mathrm{tr}$. V

ANU-75 : $315 \pm 53$ (AD 1635).

This discovery permits us to conclude that the settlement at Rakival with Lapita style decorated pottery was the first human occupation of the site about $500 \mathrm{BC}$. 


\section{External relationships of the Lapita Pottery tradition}

W.G. Soheim has suggested that studies of pottery may be used to reconstruct movements of people (Solheim, 1964a). He assumed that the people who made pottery of the so-called 'the Sa-huynh - Kalanay Pottery tradition' were speakers of MalayoPolynesian languages. This tradition is named after the site of Sa-huynh, Vietnam and the site of Kalanay in the Philippines.

The Sa-huynh complex pottery is characterized by its sophistication and variation of surface treatment, decoration and form (Solheim 1959:97 - 108; $177-188$ ). Most of the pottery is plain; cord-marked vessels are not common, but are present. Decoration is created by incising, impressing, and painting. Roulette impressions may have been obtained with some form of a dentate tool, the most common pattern of which is a series of triangles. The pottery of the Kalanay pottery complex is also sophisticated, technologically well-made pottery. Decoration is incised, impressed, carved, and painted, and the most common element of design is triangle in many varied forms. These two pottery complexes indicated sufficiently remarkably similarity to be grouped as the Sa-huynh - Kalanay tradition.

Geographical distribution of the Sa-huynh-Kalanay pottery tradition is wide, throughout the Philippines. Thailand in the neolithic site of Kanchanaburi, Indonesia in the site of Galumpang, the Buni site (West Java), and at Tjekik and Gilimanuk (Bali) down to Melanesia along the south coast of New Guinea.

The Lapita Pottery tradition shows a resemblence to the Sahuynh-Kalanay tradition (Solheim, 1964b:208 - 209). As Poulsen has already noted in his Tongan report, the decoration is done with a dentate tool. This technique was used for decoration in Malaya and in Annam. Especially in the Watom pottery, striking similarity to Sahuynh-Kalanay tradition is indicated. What we can say at present is that according to Solheim (1964a:380), the eraliest pottery so far recovered in the most distant areas of Melanesia shares a number 
of elements with the Sa-huynh - Kalanay Pottery tradition and the 'Bau-Malay' Pottery tradition originally from the Southeast Asia mainland.

On the basis of the technique of manufacture Solheim concluded tentatively that (Solheim, 1964a:382) :

"(1)Knowledge of pottery manufacture entered the Melanesian area from two different sources and has there become greatly mixed. The two sources were: (a) from the north, probably Japan; and (b) through the Philippines and Indonesia, ultimately from Southeast Asia.

(2) At some time there has been a movement from Western Micronesia, west into Eastern Indonesia.

(3) Pottery manufacturing in Mindanao probably came from Indonesia while the same general type of manufacture may have come to the Visayas and Luzon directly from the mainland of Southeast Asia; or, if coming from Indonesia, arriving before penetration from the Western Carolines which did not extend north of Mindanao in the Philippines.

(4) Either there was contact directly across New Guinea from the central, north coast to the Port Moresby region, or a cornmon culture (as far as pottery is concerned) in the Eastern half of New Guinea was interrupted by an intrusion on the southern end of the island.

(5) Migration to New Caledonia (the southern extension of pottery) brought the pottery manufacturing method from the north (1a above), while Fiji (the eastern extension) received methods from both sources".

\section{Concluding Remarks}

The study of the origins of the Polynesians has many complex problems. The hypotheses of South American-Indian origin and of Southeast Asian origins have been discussed. The former which was attested by the Kon-Tiki expedition, and then supported by serological survey, seems not to be widely accepted. On the other hand, the 
latter hypothesis is most favourable, supported by both linguistic and archaeological data.

There is a very distinctive culture within the area of Polynesia, the so-called Lapita culture. The Lapita culture provides the necessary archaeological evidence for tracing the Polynesians in a very direct way. In terms of physical anthropology, Bellwood (1978:31-53) noted that the Lapita evidences ties in geographically with the Mongoloid origins of the Polynesians in Island South-East Asia.

The Lapita pottery tradition has been located from the coasts of Santa Cruz and New Britain to the north-west of New Caledonia and to the east from new Hebrides, Fiji, Tonga and Samoa. The distribution of Lapita ware is noticeably maritime. Its external relationship with the Sa-huynh - Kalanay pottery tradition and the 'Bau - Malay' pottery tradition in Southeast Asia indicates the presence of a relationship of Polynesians with Southeast Asia people in very ancient times. Thus, it would strengthen the Southeast Asian hypothesis. However, as Ferdon (1963:505) warns us, "The problem of Polynesian origins and cultural diffusion is far too complex to be solved... The variety of possible sources and of possible routes is infinite". It is therefore recommended that more anthropological research and archaeological research in the area in question be carried out to clarify further the picture of Polynesian origins. 


\section{BIBLIOGRAPHY}

Bellwood, Peter. 1978. Polynesians, Prehistory of an island people London: Thomas and Hudson.

Benedict, Paul K. 1942. Thai, K.adai and Indonesian. A new alignment in Southeastern Asia. American Anthropologist 44:576-601.

Clark, Grahame. 1977. World Prehistory in New Perspective. 3rd edition, London, New York: Cambridge University Press.

Dixon, Roland B. 1920. A new theory of Polynesian origins. Proceeding of the American Philosophical Society vol. LIX: $261-267$.

Dixon, Roland B. 1928. The Building of Cultures. New York, London: Charles Schribner's Sons.

Ferdon, Edwin N. 1963 Polynesian origin. Science 141: 499 - 505.

Gifford, E.W. 1951. Archaeological excavations in Fiji. Anthropological Records vol. 13 No. 3 : $189-288$.

Gifford, E.W. and Shutler, Jr., Dick. 1956. Archaeological Excavations in New Caledonia. Anthropological Records vol. 18 No. 1 University of California Press.

Golson, J. 1961. Report on New Zealand, Western Polynesia, New Caledonia, and Fiji. Asian Perspectives V: $166-180$.

Grace, George W. 1964. The Linguistic Evidence. Current Anthropology vol. 5 No. 5: $361-368$.

Grace, George W. 1970. Austronesian Linguistic and Culture History. In Thomas, G. and Wallace, B.J. (eds.) Cultures of the Pacific. New York: The Free Press, London : Cllier-MacMillan Ltd. pp. $20-28$. 
Graydon, J.J. 1952. Blood Groups and the Polynesian. Mankind IV (8): $329-339$.

Green, Roger. 1966. Linguistic sub-grouping with within Polynesia: The implication for prehistoric settlement. Journal of the Polynesian Society LXXV: 6 - 38.

Green, Roger. 1973. Lapita Pottery and the Origins of Polynesian Culture. Australian National History vol. 17 (10): 332 - 337.

Groube, L.M. 1971. Tonga, Lapita Pottery, and Polynesian Origins. Journal of the Polynesian Society vol. 80 (3): $278-316$.

Hedrick, John D. 1971. Lapita Style Pottery from Malo Island. Journal of the Polynesian Society vol. 80 (1): $5-19$.

Heyerdahl, Thor. 1950a. The Kon-Tiki Expedition. London: Allen and Unwin

Heyerdahl, Thor. 1950b. The Voyage of the Rift Kon-Tiki. An Argument for American Polynesian Diffusion. Geographical Journal vol. 115: $1-3$.

Heyerdahl, Thor. 1952. American Indians in the Pacific. London: Allen and Unwin

Heyerdahl, Thor. 1961. Sea Routes to Polynesia. Expedition 4 (1): 22 $-29$.

Heyerdahl, Thor. 1968 Sea Routes to Polynesia. New York: Rand McNelly \& Co.

Li, Hui-Lin. 1970. The Origin of Cultivated Plants in Southeast Asia. Economic Botany 24: 3- 19.

Oliver, D.I. 1961. The Pacific Islands. Rev. ed. New York.

Palmer, J.B. 1966. Lapita Style Potsherds from Fiji. Journal of the Polynesian Society 75 (3): 373 - 377.

Poulsen, J. 1964. Preliminary Report on Pottery Finds in Tonga. Asian Perspectives VIII: $184-195$. 
Sauer, Carl O. 1952. Agricultural Origins and Dispersal. New York: The American Geographical Society.

Sharp, Andrew. 1956. Ancient voyagers in the Pacific. Wellington: Polynesian Society.

Sharp, Andrew. 1956. 1963. Ancient voyagers in Polynesia. Auckland : Paul's.

Shuttler Jr., Richard and Marek, Jeffrey C. 1975. On the dispersal of the Austronesian horticulturalists. Archaeology \& Physical Anthropology in Oceania vol. X (2): 81 - 113.

Simmons, R.T. 1961. Blood Groups genes in Polynesians and comparisons with other Pacific peoples. Oceania XXXII (1): 198 - 210.

Simmons, R.T., Graydon, J.J., Semple, N.M., and Fry, E.I. 1955. A blood group genetical survey in Cook Islanders, Polynesia, and comparisons with American Indians. American Journal Physical Anthropology 13: 667 690.

Simmons, RT. and Graydon, J.J. 1957. A blood group genetical survey in Eastern and Central Polynesians. American Journal Physical Anthropology 15 (3): 357 - 366.

Solheim II, W.G. 1959. Introduction to Sa-huynh. Asian Perspectives III: 97 - 108.

Solheim II, W.G. 1959. Sa-huynh Related Pottery in Southeast Asia Asian Perspectives III : 177 - 188.

Solheim II, W.G. 1962. Eastern Asia and Oceania. Asian Perspectives V (1): $5-15$.

Solheim II, W.G. 1964a. Pottery and the Malayo-Polynesians. Current Anthropology vol. 5 No. 5 : 360 - 406.

Solheim II, W.G. 1964b. Further Relationships of the Sa-huynh - Kalanay Pottery Tradition. Asian Perspectives VIII : 196 - 211.

Specht, J. 1968 Preliminary Report of Excavations on Watom Island. Journal of the Polynesian Society 77 (2): 117 - 134. 
Suggs, Robert C. 1970. The Kon-Tiki Myth. In Harding T.G and Wallace, B.J. (eds.) Cultures of the Pacifics. New York: The Free Press London: Collier-MacMillan, Ltd. pp. $29-38$.

Swindler. Daris R. 1968. Problem of Melanesian Racial History.

Wurm, S.A. 1967. Linguistics and the Prehistory of the South-western Pacific. Journal of the Pacific History vol. 2: $25-38$. 